\title{
Improvement of the secondary cooling mode for continuous casting of round billets at Ural Steel JSC
}

\author{
A. N. Shapovalov, Cand. Eng., Associate Prof., Deputy Director on Innovations and Development ${ }^{1}$, \\ e-mail:alshapo@yandex.ru \\ R. R. Dema, Cand. Eng., Associate Prof.2, e-mail: demarr78@mail.ru \\ R. N. Amirov, Cand. Eng., Associate Prof. ${ }^{2}$ \\ O. R. Latypov, Engineer of Scientific and Innovation Center2, e-mail: latolegraf@list.ru
}

${ }^{1}$ National University of Science and Technology "MISiS", Novotroitsk Branch, Novotroitsk, Russia

${ }^{2}$ Nosov Magnitogorsk State Technical University, Magnitogorsk, Russia

\begin{abstract}
Formation of hot cracks on continuously cast round billets is the frequent problem in metallurgical production. The article presents the results of a study of the macrostructure, surface quality and technology of continuous casting of round billets with a diameter of $455 \mathrm{~mm}$, produced at the bloom caster of Ural Steel JSC. The main defects of such billets are identified as surface cracks of "combined" type, namely, transverse cracks (the share among the billets with defects is $9.1 \%$ ), cracks of the mesh form (the share among the billets with defects is $8.3 \%$ ). The main reasons for the unsatisfactory quality of the ingot are determined: increased overheating of metal in the tundish, which can be partially compensated by reduction of the casting speed, and intensive cooling of billet surface in the first segments of secondary cooling, which increase thermal stresses in metal with consequent heating of surface layers. It was decided that the most effective way to minimize billet defects is to improve the secondary cooling technology in compliance with the regulated casting temperature and speed procedure. Thermal calculations of billet solidification are conducted. It was revealed that overcooling of billet surface occurs in the first segments of secondary cooling under the existing secondary cooling modes and temperature and speed modes of casting, which leads to additional thermal and phase stresses. In the third segment of the secondary cooling zone, heating of the billet surface is observed due to the heat of the central part. Rational flow rates of cooling agent for the secondary cooling segments of the bloom continuous casting machine are proposed. They include expansion of the active section of secondary cooling with a reduction of cooling agent consumption in the first segments will reduce the thermal cycling processes in the hardened crust and minimize the likelihood of cracking.
\end{abstract}

Key words: continuous casting, round billet, casting parameters, secondary cooling zone, railway wheel steel.

DOI: $10.17580 /$ cisisr.2021.02.03

\section{Introduction}

Continuous casting is at present time the main production method for steel billets, because it provides high yield, required productivity and regularity of up-to-date steelmaking production. However, continuous casting technology is connected with arising of increased stresses in hardened crust, what can lead to forming of hot cracks on the surface and across the section of billet [1-5], which deteriorate billet quality. Round continuously cast billet is especially sensitive to forming of hot cracks [6-9]. Analysis of the results of numerous investigations [6-11] displays that metal plasticity fall due to irrational temperature and speed casting mode and secondary cooling procedure are the main causes of hot cracks forming. At the same time, despite the large amount of publications devoted to this theme, the problems of quality improvement of continuously cast billet and optimization of technical and economical casting parameters can be solved in general individually in each single case. Thereby scientific and technical literature includes a lot of publications describing simulation of the heat state of a continuously cast billet $[8,9,12-16]$, as well as the results of investigations aimed on modernization of equipment and improvement of technologies for continuous casting in different production conditions: Pangang Group Chengdu Steel (China) [9], Hebei Iron \& Steel Group (China) [10, 17], Xingtai Steel (China) [18], Panzhihua Steel (China) [19], Zhongyuan Special Steel (China) [20], Voestalpine Stahl (Austria) [21, 22], "Ural Steel” (Russia) [23-25], "UMMC-Steel” (Russia) [26], Mini-metallurgical plant "ISTIL" (Ukraine) [27].

Thereby, solutions of the billets quality problems for continuous casting machines can be quite various, depending on the properties of cast steels, billets cross sections as well as technical and technological parameters of continuous casters. Based on multifactorial aspects of the considering problem, the variants of its solving should be chosen individually, taking into account each continuous caster and its dimension range. That's why examination

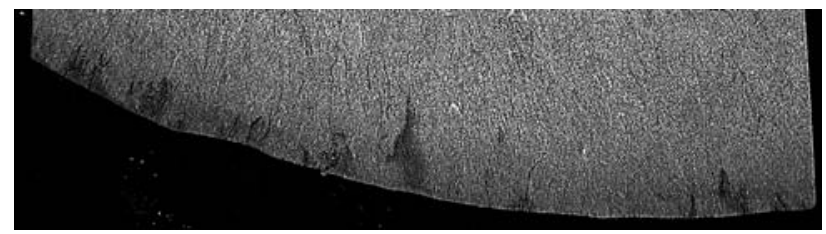

Fig. 1. Surface and subsurface cracks in billet transversal cross section 


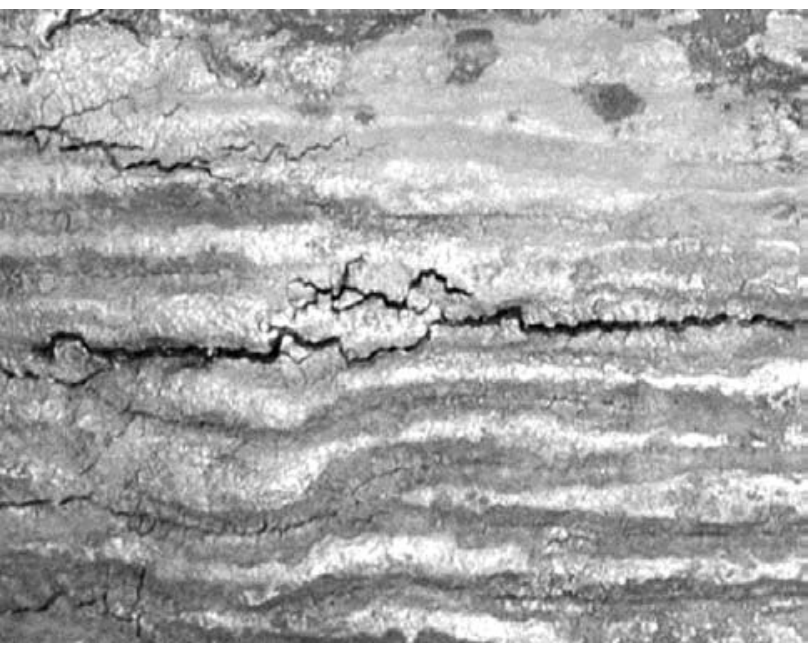

a)

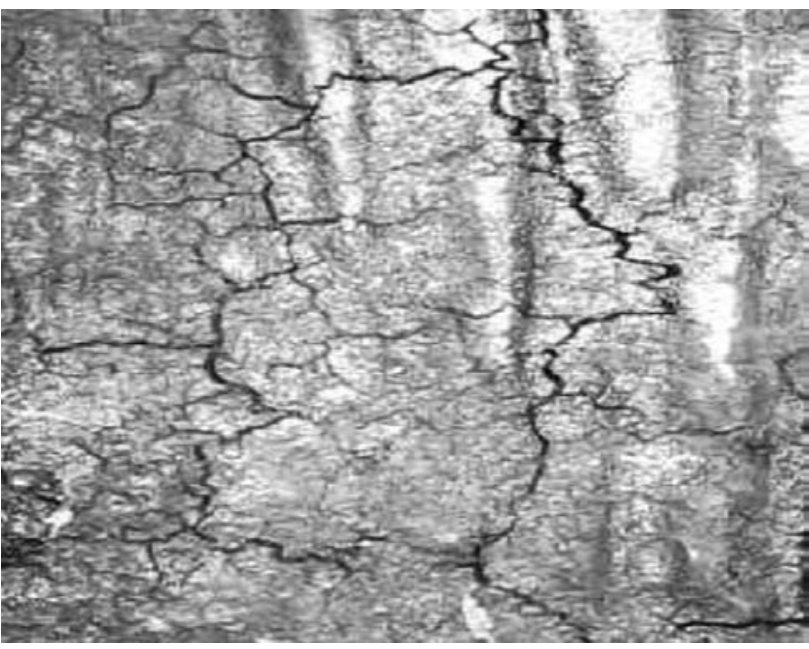

b)

Fig. 2. Dynamic scheme of interaction between grinding wheel and billet: $a-$ at the initial time; $b-$ during grinding

of the casting technology and billet quality in the concrete production conditions allows to obtain the new regularities and to improve production technology, despite large amount of studies in the field of steel continuous casting. So, the data on quality of continuously cast billet and influence of the casting technology on its parameters applying to the operating conditions of 4-strand bloom caster at "Ural Steel" are absent within the wide open access.

\section{Aim and object of investigation}

Improvement of continuous casting technology for round billets on the base of analysis of production data on billet quality and casting parameters is the aim of this work. This investigation was conducted based on operation of 4-strand bloom curved-type continuous caster at "Ural Steel". This continuous caster provides casting of round billets with diameter 430, 455, 540 and $600 \mathrm{~mm}$ and rectangular billets with cross sections $300 \times 330$ and $330 \times 470 \mathrm{~mm}$ with annual designed productivity up to $950,000 \mathrm{t}$.

\section{Quality analysis of a round billet}

The work has examined the casting conditions and results for the billets with diameter $455 \mathrm{~mm}$ of railroad wheel steels (steel grade "2" according to the GOST 10791-2011) during 2019.
2,849 melts were cast during the examined period and 41,041 round billets with total mass more than $300,000 \mathrm{t}$ were obtained.

The results of macrostructure quality evaluation for the round billets with diameter $455 \mathrm{~mm}$ of steel grade " 2 " are presented in the Table $\mathbf{1}$.

The results of metallographic investigations of macrostructure in transversal templates show that the average values of defects are located within the preset limits. However, within the range of whole examined party, amount of templates with exceeding of maximal ball achieves $15.5 \%$ (by axial porosity) and $18.5 \%$ (by internal hot cracks). It is shown that high axial porosity is caused by steel casting with increased overheating $[16,19,26]$, while substantial development of internal hot cracks testifies on irrational procedure of secondary cooling $[1-4,6-11,15,18]$.

Macrographic studies of billets cross section displayed presence of surface and subsurface cracks starting from the depth 5-10 $\mathrm{mm}$ from the surface in radial direction; their depth makes 2-40 mm (Fig. 1). Crack propagation inside cross section occurs along the boundaries of former austenite grains.

It was revealed as a result of surface quality analysis for round billets that mostly often defects are surface cracks of "combined" type; they can be classified conditionally in the following way:

\begin{tabular}{|l|c|c|c|c|}
\hline \multicolumn{1}{|c|}{ Table 1. Macrostructure quality of continuously cast billet } \\
\hline Macrostructure defects & Variation range, balls & Average values, balls & $\begin{array}{c}\text { Allowable value of } \\
\text { defect development, } \\
\text { balls }\end{array}$ & $\begin{array}{c}\% \text { of templates with } \\
\text { exceeding of allow- } \\
\text { able balls* }\end{array}$ \\
\hline Central porosity (CP) & $0.5-4.0$ & 1.19 & 2.0 & 15.5 \\
\hline Axial segregation (AS) & $1.0-2.5$ & 0.99 & 2.0 & 0.5 \\
\hline $\begin{array}{l}\text { Segregation strips and cracks across } \\
\text { the section (SSaCS) }\end{array}$ & $0.5-2.0$ & 0.34 & 1.0 & 6.9 \\
\hline $\begin{array}{l}\text { Segregation strips and axial cracks } \\
\text { (SSaAC) }\end{array}$ & $0.5-3.0$ & 0.42 & 1.0 & 18.5 \\
\hline * from total amount of 11,968 examined templates & & & \\
\hline
\end{tabular}




\begin{tabular}{|l|c|c|}
\hline \multicolumn{2}{|c|}{ Table 2. Casting technological parameters } \\
\hline \multicolumn{2}{|c|}{$\begin{array}{c}\text { Range of } \\
\text { variation }\end{array}$} & $\begin{array}{c}\text { Average } \\
\text { value }\end{array}$ \\
\hline Number of melts, un. & \multicolumn{2}{c|}{2849} \\
\hline Chemical composition, \% & $0.6-0.62$ & 0.61 \\
carbon & $0.64-0.72$ & 0.67 \\
manganese & $0.25-0.33$ & 0.28 \\
silicon & $0.003-0.005$ & 0.004 \\
vanadium & $0.002-0.010$ & 0.003 \\
sulfur & $0.005-0.020$ & 0.010 \\
phosphorus & $0.004-0.008$ & 0.072 \\
nitrogen & $0.7-2.0$ & 1.4 \\
hydrogen, ppm & $0.26-0.44$ & 0.36 \\
\hline Pulling speed, $\mathrm{m} / \mathrm{min}$ & \multicolumn{2}{|c|}{0.30} \\
\hline Pulverization plan, $\mathrm{l} / \mathrm{kg}$ & $1490-1520$ & 1500.5 \\
\hline Metal temperature in tundish, ${ }^{\circ} \mathrm{C}:$ & $15.4-45.6$ & 26.7 \\
\hline Metal overheating in tundish, ${ }^{\circ} \mathrm{C}:$ & \multicolumn{2}{|c|}{} \\
\hline
\end{tabular}

- transverse cracks (main component), usually located in the bottom part of tracks of mould oscillation (Fig. 2a), with small longitudinal branches, presented on 44 from 483 examined billets (what makes $9.1 \%$ );

- cracks of the mesh form (Fig. $2 \boldsymbol{b}$ ), presented on 40 from 483 examined billets (what makes $8.3 \%$ ).

Thereby, it can be concluded based on the results of macrostructure and surface studies for continuously cast round billers with diameter $455 \mathrm{~mm}$, that the casting technology requires to be improved.

\section{Analysis of casting conditions}

A lot of factors have influence on billet quality, among them the following ones can be mentioned: steel chemical composition (which determinates metal behaviour and its properties during casting) as well as construction and technological parameters of casting. Properties of cast steel and casting parameters make the decisive effect on billet quality during analysis of operation of the concrete continuous caster. Steel chemical composition and casting parameters during the examined period are presented in the Table 2 .

Composition of cast steel meets the up-to-date requirements of continuous casting, thereby the main problem of obtaining high-quality billets concludes in observation of rational casting parameters.

The temperature and speed casting parameters (see Table 2) vary in wide range, while the maximal overheating values exceed the level which is present by the technological specification: $15-30{ }^{\circ} \mathrm{C}$ for more than $10 \%$ of melts. Casting with increased overheating values supports development of axial segregation and porosity, as well it can be the cause of forming internal and surface cracks which appear in the conditions of essential thermal stresses inside metal [5, 11-13, 16-26]. Increased metal overheating in the tundish can be partly compensated by decrease of casting speed; however, it leads to reducing of continuous caster productivity and has negative reflection on a billet quality due to varying of thermal conditions of solidification. Thereby technological staff uses the method of casting speed decrease only in the case of bursting danger.

\section{Examination of thermal conditions of solidification}

The billet surface temperature was measured in 6 points along the technological length of continuous caster in order to evaluate thermal conditions of billet solidification. These measurements were conducted using Flir T640 thermal imager during casting of 25 melts of steel grade " 2 " with producing of round billets with diameter $455 \mathrm{~mm}$. Normal overheating was within the range $15-30{ }^{\circ} \mathrm{C}$. The results of billet surface temperature measurements are presented in the Table 3.

The obtained data on temperature dynamics of continuously cast billets along their length testify on non-effective tuning of secondary cooling. So, intensive cooling of billet surfaces in the first secondary cooling segments with consequent heating of surface layers induces appearing of additional thermal stresses in solidified metal, what is considered as the main cause of forming of cracks with different form and depth [1-10]. In addition to this, billet straightening within the temperature range from 900 to $700{ }^{\circ} \mathrm{C}$, which corresponds to the interval of $\gamma \rightarrow \alpha$ transformation, is the additional cause of appearance of transverse cracks, especially on tracks of mould oscillation.

It can be concluded on the base of the obtained data on the thermal conditions of round billets forming, that correction of secondary cooling intensity with observation of preset temperature procedure of casting is required for improvement of billet quality.

\section{Calculation of secondary cooling rational procedure}

In order to improve the secondary cooling procedures, calculation of cooling agent consumption was made for the secondary cooling segments. This calculation is valid for casting of steel grade " 2 " to the round billet with diameter $455 \mathrm{~mm}$.

Calculation of secondary cooling conditions was conducted taking into account the obtained experimental data on billet surface temperature values, based on regularities of heat transfer in the secondary cooling zone. This method used 2D thermal solidification model $[6,8,9]$ in the polar coordinate system (without taking into account variations of billet dimensions). Steel casting conditions include normal

\begin{tabular}{|l|l|c|c|c|}
\hline \multicolumn{5}{|l|}{$\begin{array}{l}\text { Table 3. Results of surface temperature measurements for round billets } \\
\text { with diameter } \mathbf{4 5 5} \text { mm }\end{array}$} \\
\hline Points of measurements & $\begin{array}{c}\text { Distance from } \\
\text { metal level in } \\
\text { the mould, } \\
\text { mm }\end{array}$ & \multicolumn{2}{|c|}{ Billet surface temperature, ${ }^{\circ} \mathrm{C}$} \\
\cline { 3 - 6 } & 890 & 1048 & 1196 & 1103.2 \\
\hline Exit from the mould & 4970 & 894 & 1052 & 974.3 \\
\hline Exit from the segment 1 & 9420 & 961 & 1124 & 101.6 \\
\hline Exit from the segment 2 & 16100 & 881 & 1015 & 953.2 \\
\hline Exit from the segment 3 & 25430 & 839 & 986 & 913.1 \\
\hline Exit from the segment 4 & 26950 & 826 & 971 & 908.4 \\
\hline Exit from the straightening area & & & & \\
\hline
\end{tabular}


$\left(15-30{ }^{\circ} \mathrm{C}\right)$ overheating with pulling speed $\mathrm{w}=0.44 \mathrm{~m} / \mathrm{min}$ and increased (more than $30^{\circ} \mathrm{C}$ ) metal overheating in the tundish with pulling speed $\mathrm{w}=0.36 \mathrm{~m} / \mathrm{min}$.

Determination of rational water consumption in secondary cooling zone segments was based on the condition of smooth lowering of the billet surface temperature without failures of technological plasticity (above $900-1000{ }^{\circ} \mathrm{C}$, depending on steel chemical composition). The billet surface temperature in the exit of the secondary cooling zone was taken in this calculation as constant value $\left(950^{\circ} \mathrm{C}\right)$.

Water consumption values in the secondary cooling zones - used (according to the technological specification - TS) and optimal - are presented in the Table 4.

The results of thermal calculation (see Table 4) testify that cutting and redistribution of water consumption between the segments of secondary cooling zone are required for optimization of thermal solidification conditions for a round billet with diameter $455 \mathrm{~mm}$, made of steel grade " 2 ". So, total decrease of water consumption by $27.8 \%$ (for normal metal overheating) and by $39.1 \%$ (for steel casting with increased overheating) is required for optimization of temperature conditions of round billet forming in the secondary cooling zone, taking into account extension of segments and billet pulling speed. Expansion of the active section of secondary cooling with simultaneous cutting of the cooling agent consumption in the first segments allow to decrease the thermal cycling processes in solidified crust and to provide favourable surface temperature during straightening.

Calculated data on the surface temperature dynamics for round billets with diameter $455 \mathrm{~mm}$ within the secondary cooling zone are presented on the Fig. 3; current and calculated consumption of cooling agent were made for normal overheating within the range $15-30^{\circ} \mathrm{C}$.

The data of the Fig. 3 show that billet surface overcooling in the first secondary cooling segments occurs at the existing and operating secondary cooling procedures and temperature and speed casting modes. It leads to additional thermal and phase stresses which deteriorate billet quality. Billet surface heating due to central part heat is observed in the third segment of the secondary cooling zone. Calculated modes of secondary cooling provide more favourable and smooth billet surface temperature decrease, while the temperature corresponds to the zone of metal plastic state; it minimizes likelihood of cracking.

In this connection, based on the results of conducted calculations, the optimal procedures of secondary cooling were

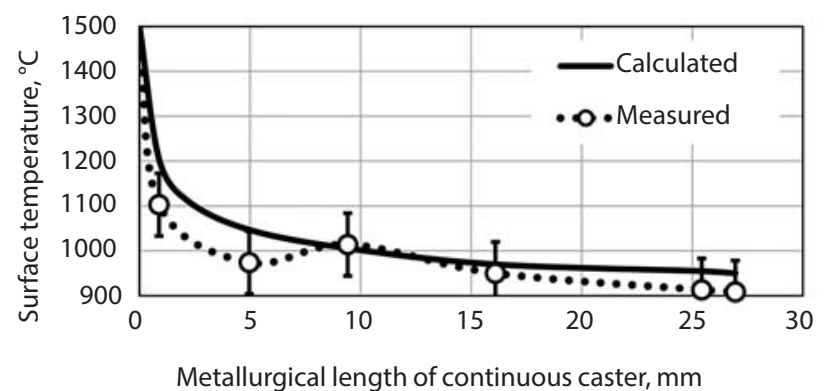

Fig. 3. Surface temperature dynamics for round billets with diameter $455 \mathrm{~mm}$ for actual and optimal consumption of cooling agent within the secondary cooling

developed; they provide the favourable solidification conditions and promote quality improvement for continuously cast round billets with diameter $455 \mathrm{~mm}$ from steel grade " 2 ". The obtained secondary cooling procedures are available also for casting of other steel grades for railroad transport.

\section{Conclusions}

Analysis of production data on casting of round billets with diameter $455 \mathrm{~mm}$, made of steel grade "2", at the bloom continuous caster of "Ural Steel" JSC allowed to establish the main causes of unsatisfactory billet quality, which conclude in excessive overheating and irrational secondary cooling procedure. The conducted examination of surface quality of round billets in the secondary cooling zone confirmed insufficient efficiency of secondary cooling procedure.

The results of thermal calculations of solidification for round billets with diameter $455 \mathrm{~mm}$, made of steel grade " 2 ", displayed that expanding of the active section of secondary cooling with simultaneous cutting the expenses for cooling agent is required for improvement of thermal conditions of billet forming. It means that, taking into account length of the segments and speed of billet pulling, total decrease of water consumption by $27.8 \%$ (for normal metal overheating) and by $39.1 \%$ (during steel casting with increased overheating) was necessary for optimization of the temperature conditions of round billet forming in the secondary cooling zone.

More soft secondary cooling, providing likelihood of development of surface and internal billet defects, is provided at the optimized conditions of secondary cooling which are

\begin{tabular}{|c|c|c|c|c|c|c|}
\hline \multirow{3}{*}{$\begin{array}{l}\text { Segments of the secondary } \\
\text { cooling zone }\end{array}$} & \multirow{3}{*}{$\begin{array}{l}\text { Length of seg- } \\
\text { ments of the sec- } \\
\text { ondary cooling } \\
\text { zone, mm }\end{array}$} & \multirow{3}{*}{$\begin{array}{l}\text { Cooling } \\
\text { procedure }\end{array}$} & \multicolumn{4}{|c|}{ Water consumption, I/min, for different metal overheating } \\
\hline & & & \multicolumn{2}{|c|}{$\begin{array}{c}\text { Normal overheating } \\
\left(15-30^{\circ} \mathrm{C}\right) \text { at pulling speed } \\
\mathrm{w}=0.44 \mathrm{~m} / \mathrm{min}\end{array}$} & \multicolumn{2}{|c|}{$\begin{array}{l}\text { Increased overheating } \\
\text { (more than } 30^{\circ} \mathrm{C} \text { ) at pulling } \\
\text { speed } \mathrm{w}=0.36 \mathrm{~m} / \mathrm{min}\end{array}$} \\
\hline & & & $\begin{array}{l}\text { According } \\
\text { to TS }\end{array}$ & Optimal & $\begin{array}{l}\text { According } \\
\text { to TS }\end{array}$ & Optimal \\
\hline Zone 1 & 240 & Jet (water) & 33.2 & 10.76 & 28.4 & 9.41 \\
\hline Segment 1 & 4080 & \multirow{4}{*}{ Water and air } & 81.2 & 34.66 & 66.8 & 26.39 \\
\hline Segment 2 & 4450 & & 35.2 & 29.58 & 29.2 & 21.20 \\
\hline Segment 3 & 6680 & & 22 & 20.01 & 18 & 11.78 \\
\hline Segment 4 & 9330 & & 0 & 5.91 & 0 & 4.22 \\
\hline
\end{tabular}


characterized by more smooth feed of cooling agent. Lowering of specific production expenses due to increase of yield of finished billets is expected as a result of putting into practice the rational secondary cooling procedures. Quantitative effect on introduction of the developed technological modes will be determined after finishing the pilot-industrial tests.

The work was conducted under financial support of the RF Ministry of Science and High Education (project No. FZRU-2020-0011).

\section{REFERENCES}

1. Brovman M. Ya. Continuous casting of metals. Moscow. EKOMET. 2007. $484 \mathrm{p}$

2. Parshin V. M., Bulanov L. V. Continuous casting of steel. Lipetsk. "NLMK" JSC. 2011. 221 p.

3. Smirnov A. N., Kuberskiy S. V., Shtepan E. V. Continuous casting of steel: a manual. Donetsk. DonNTU. 2011. 482 p.

4. Flesch R., Bleck W. Crack susceptibility of medium and high alloyed tool steels under continuous casting conditions. Steel Research. 1998. Vol. 69. No. 7. pp. 292-299.

5. Alvarez de Toledo G., Arteaga A., Laraudogoitia J. J. Continuous Casting of Microalloyed Steels. Influence of Composition and Operational Parameters in Billet Surface Cracking. Materials Science Forum. 2005. Vol. 500-501. pp. 163-170.

6. Zhang J. et al. Effects of an even secondary cooling mode on the temperature and stress fields of round billet continuous casting steel. Journal of Materials Processing Technology. 2015. Vol. 222. pp. 315-326.

7. Fan H., Long M., Yu S. et al. Uniform Secondary Cooling Pattern for Minimizing Surface Reheating of the Strand During Round Bloom Continuous Casting. Journal of Minerals, Metals \& Materials Society (JOM). 2018. Vol. 70. pp. 237-242.

8. Wang R., Bao Y.-P., Li Y.-H., An H.-H. Optimization of secondary cooling in continuous casting of round billet. Metallurgical Research and Technology. 2015. Vol. 112. p. 302.

9. Long M., Dong Z., Sheng J., Chen D., Chen C. Universal Secondary Cooling Structure for Round Blooms Continuous Casting of Steels in Various Diameters. Steel Research International. 2015. Vol. 86. No. 2. pp. 154-162.

10. Chen W., Zhang Y.-Z., Zhang C.-J., Zhu L.-G., Wang S.-M., Wang B.-X., Ma J.-H., Lu W.-G. Thermomechanical analysis and optimisation for beam blank continuous casting. Ironmaking \& Steelmaking. 2008. Vol. 35. No. 2. pp. 129-136.

11. Chen W., Zhang Y.-Z., Wang B.-X. Optimisation of continuous casting process parameters based on coupled heat and stress model. Ironmaking \& Steelmaking. 2010. Vol. 37. No. 2. pp. 147-154.

12. Long M.J., Chen D.F., Zhang J., Ouyang Q. Novel online temperature control system with closed feedback loop for steel continuous casting. Ironmaking \& Steelmaking. 2013. Vol. 38. No. 8. pp. $620-629$.
13. Wang X., Wang Z., Liu Y., Du F., Yao M., Zhang X. A particle swarm approach for optimization of secondary cooling process in slab continuous casting. International Journal of Heat and Mass Transfer. 2016. Vol. 93. pp. 250-256.

14. Chakraborti N., Gupta R. S. P., Tiwari T. K. Optimisation of continuous casting process using genetic algorithms: studies of spray and radiation cooling regions. Ironmaking \& Steelmaking. 2003. Vol. 30. No. 4. pp. 273-278.

15. Ji C., Cai Z. Z., Wang W. L., Zhu M. Y., Sahai Y. Effect of transverse distribution of secondary cooling water on corner cracks in wide thick slab continuous casting process. Ironmaking \& Steelmaking. 2014. Vol. 41. No. 5. pp. 360-368.

16. Sun H., Li L. Formation and control of macrosegregation for round bloom continuous casting. Ironmaking \& Steelmaking. 2015. Vol. 42. No. 9. pp. 683-688.

17. Luo W., Yan B., Xiong Y. X., Wen G. H., Xu H. L. Improvement to secondary cooling scheme for beam blank continuous casting. Ironmaking \& Steelmaking. 2012. Vol. 39. No. 2. pp. 125-132.

18. Zong N., Zhang H., Liu Y., Lu Zh. Analysis on morphology and stress concentration in continuous casting bloom to learn the formation and propagation of internal cracks induced by soft reduction technology. Ironmaking \& Steelmaking. 2019. Vol. 46. No. 9. pp. 872-885.

19. Pan H. Control Technology of Internal Quality for CC Billet. Advanced Materials Research. 2012. Vol. 415-417. pp. 1729-1734.

20. Zhang L.W., Wang Z. L., Xu C. J. et al. A vertical continuous casting machine for large blooms. Ironmaking \& Steelmaking. 2019. Vol. 46. No. 8. pp.742-746.

21. Barna M., Javurek M., Reiter J. et al. Numerical Simulations of Mould Electromagnetic Stirring for Round Bloom Strands. Bergische und Huettenmaennische Monatshefte. 2009. Vol. 154. p. 518

22. Rauter W., Reiter J., Srienc K. et al. Soft Reduction at a Round Bloom Caster: Implementation and Results. Bergische und Huettenmaennische Monatshefte. 2014. Vol. 159. pp. 454-460.

23. Tutarova V. D., Safonov D. S., Shapovalov A. N. Density distribution of the spray from flat spray nozzles in the secondary-cooling zone of a continuous caster. Metallurgist. 2012. Vol. 56. No. 5-6. pp. 438-442.

24. Shevchenko E. A., Stolyarov A. M., Shapovalov A. N., Baranchikov K. V. Transverse distortion of continuous-cast slab. Steel in Translation. 2014. Vol. 44. No. 1. pp. 17-20.

25. Shevchenko E. A., Stolyarov A. M., Shapovalov A. N., Baranchikov K. V. Preventing convexity at the narrow faces of continuouscast billet. Steel in Translation. 2015. Vol. 1. pp. 29-32.

26. Kalitaev A. N., Tutarova V. D., Shapovalov A. N. Effect of Continuous Casting Parameters on Quality of Billets Manufactured by UMMC Steel LLC. Solid State Phenomena. 2017. Vol. 265. pp. 952-961.

27. Kasyan G. I., Pisarskiy S. N., Sirchenko V. I. Experience of mastering and improvement of production technology for round section billets at the continuous casting machine in the electric steel melting shop of the Mini-metallurgical plant "ISTIL" (Ukraine). Metall i lityo Ukrainy. 2009. No. 3. pp. 6-9. 